\title{
Abomasal amino acid infusion in postpartum dairy cows: Effect on whole-body, splanchnic, and mammary glucose metabolism
}

\author{
C. Galindo, ${ }^{*}$ M. Larsen, † D. R. Ouellet, $\ddagger$ G. Maxin,$\ddagger^{1}$ D. Pellerin, ${ }^{*}$ and H. Lapierre $\ddagger^{2}$ \\ *Département de Sciences Animales, Université Laval, Québec, QC, Canada, G1V 0A6 \\ †Department of Animal Science, Aarhus University, Foulum, DK-8830 Tjele, Denmark \\ ‡Dairy and Swine Research and Development Centre, Agriculture and Agri-Food Canada, Sherbrooke, QC, Canada J1M 0C8
}

\begin{abstract}
Nine Holstein cows fitted with rumen cannulas and indwelling catheters in splanchnic blood vessels were used to study the effects of supplementing AA on milk lactose secretion, whole-body rate of appearance (WB-Ra) of glucose, and tissue metabolism of glucose, lactate, glycerol, and $\beta$-OH-butyrate (BHBA) in postpartum dairy cows according to a generalized randomized incomplete block design with repeated measures in time. At calving, cows were blocked according to parity (second and third or greater) and were allocated to 2 treatments: abomasal infusion of water $(\mathrm{n}=4)$ or abomasal infusion of free AA with casein profile $(\mathrm{AA}-\mathrm{CN} ; \mathrm{n}=5)$ in addition to the same basal diet. The AA-CN infusion started with half the maximal dose at $1 \mathrm{~d}$ in milk (DIM) and then steadily decreased from 791 to $226 \mathrm{~g} / \mathrm{d}$ from DIM 2 to 29 to cover the estimated essential AA deficit. On DIM 5, 15, and 29, $\mathrm{D}\left[6,6-{ }^{2} \mathrm{H}_{2}\right]$-glucose $(23.7 \mathrm{mmol} / \mathrm{h})$ was infused into a jugular vein for $5 \mathrm{~h}$, and 6 blood samples were taken from arterial, portal, hepatic, and mammary sources at 45-min intervals, starting $1 \mathrm{~h}$ after the initiation of the $\mathrm{D}\left[6,6-{ }^{2} \mathrm{H}_{2}\right]$ glucose infusion. Trans-organ fluxes were calculated as veno-arterial differences times plasma flow (splanchnic: downstream dilution of deacetylated para-aminohippurate; mammary: Fick principle using Phe+Tyr). Energy-corrected milk and lactose yields increased on average with AA-CN by $6.4 \mathrm{~kg} / \mathrm{d}$ and $353 \mathrm{~g} / \mathrm{d}$, respectively, with no DIM $\times$ treatment interaction. Despite increased AA supply and increased demand for lactose secretion with AA-CN, net hepatic release of glucose remained unchanged, but WB-Ra of glucose tended to increase with AA-CN. Portal true flux of glucose increased with AA-CN and represented, on average, $17 \%$ of WB-Ra. Splanchnic true flux of glu-
\end{abstract}

\footnotetext{
Received October 24, 2014.

Accepted March 19, 2015.

${ }^{1}$ Current address: INRA UMR 1213 Herbivores, Site de Theix, F-63122, Saint-Genès-Champanelle, France.

${ }^{2}$ Corresponding author: Helene.Lapierre@agr.gc.ca
}

cose was unaltered by treatments and was numerically equivalent to WB-Ra, averaging 729 and $741 \mathrm{mmol} / \mathrm{h}$, respectively. Mammary glucose utilization increased with AA-CN infusion, averaging $78 \%$ of WB-Ra, and increased gradually as lactation advanced. Net portal, hepatic, splanchnic, and mammary fluxes of lactate, glycerol, and BHBA were not affected by AA infusion. Increasing the supply of AA in postpartum dairy cows elevated the WB-Ra of glucose without affecting the true liver glucose release. The greater WB-Ra of glucose with abomasal AA infusion seemed to originate mainly from greater true portal-drained viscera release of glucose. Glucose utilization by the portal-drained viscera was unaffected by abomasal AA infusion, but the exact mechanism behind the greater true portal glucose release could not be assessed in the current study. The increased mammary glucose uptake was in line with the increased milk lactose yield. In early postpartum lactation, the demand for AA seems to be so high that even with increased AA supply, cows have metabolic priorities for AA other than hepatic gluconeogenesis.

Key words: dairy cow, transition, glucose, amino acid

\section{INTRODUCTION}

The transition period between late pregnancy and early lactation, including the last 3 wk before parturition to 3 wk after parturition (Grummer, 1995), requires dramatic physiological and metabolic adaptations in the dairy cow. In early lactation, the mammary requirements for energy are several times that of the uterus (Bell, 1995), and nutrient demand to support milk secretion surpasses nutrient intake (Drackley et al., 2001). Consequently, dairy cows enter a period of negative energy balance in the postpartum transition period. To mitigate the deficiency of energy supply, a range of metabolic processes is present in the cow. For example, hepatic gluconeogenesis and mobilization of body reserves are upregulated to compensate the limited energy supply after calving (Ingvartsen, 2006). Despite this known energy deficiency, increasing energy supply through glucose infusion immediately 
after calving has not been successful in increasing milk production (Ørskov et al., 1977; Larsen and Kristensen, 2009). On the other hand, infusing casein during the postpartum period drastically increased milk and milk lactose yields (Ørskov et al., 1977; Larsen et al., 2014).

In cows after peak lactation, casein supplementation increases both whole-body rate of appearance (WBRa) of glucose and lactose yield (Lapierre et al., 2010). It is not known, however, whether the positive response of milk lactose yield to protein supplementation observed during the close postpartum period (Larsen et al., 2014) is also accompanied by an increased WB-Ra of glucose. In fact, although net portal absorption of AA increased from precalving to early postcalving, net hepatic removal of AA did not change (Doepel et al., 2009; Dalbach et al., 2011), whereas net hepatic release of glucose increased from pre- to postcalving (Doepel et al., 2009; Raun and Kristensen, 2011). In the immediate postpartum period, liver glucose release is supported by important inter-organ transfer of glucogenic carbons, such as lactate from peripheral tissues to the liver, instead of an increased utilization of AA for gluconeogenesis (Larsen and Kristensen, 2013). This suggests that the limited role of AA to hepatic glucose synthesis in the postpartum transition period may be due to their scarcity.

Increased AA supply could also affect portal-drained viscera (PDV) metabolism. Infusion of AA could salvage glucose for mammary use by decreasing glucose utilization by the PDV. Both EAA and NEAA contribute significantly to energy expenditure across the PDV (Lobley and Lapierre, 2003). Therefore, with increased AA supply, the PDV could use less glucose either from arterial supply or from starch digested in the small intestine: both mechanisms would salvage glucose for mammary use but only the latter would increase WBRa of glucose. It has also been reported that abomasal casein infusion stimulates the secretion of pancreatic $\alpha$-amylase (Richards et al., 2003; Swanson et al., 2004), which would increase starch digestion and glucose availability.

Therefore, the hypotheses of the present study were that increasing AA supply postcalving would (1) increase WB-Ra of glucose through an increased net hepatic release, and (2) decrease utilization of glucose by the PDV, both of which would increase glucose availability for mammary usage. Therefore, the objectives of this experiment were to determine how an increased supply of AA during the first 4 wk postpartum affects (1) ECM and lactose yields; (2) WB-Ra of glucose; (3) portal, hepatic, and mammary true fluxes of glucose; and (4) the splanchnic and mammary net fluxes of lactate and BHBA, and peripheral concentration of NEFA.

\section{MATERIALS AND METHODS}

\section{Animals and Treatments}

Four second-lactation, 4 third-lactation, and 1 fourth-lactation Holstein cows were used for the study. Cows were prepared before calving, as described in the companion paper (Larsen et al., 2015), with a rumen cannula of $10 \mathrm{~cm}$ diameter and catheters in the portal, 1 hepatic, and 2 mesenteric veins, and 1 mesenteric artery. All cows were offered the same prepartum and postpartum rations (Table 1). The postpartum ration was balanced to provide $100 \%$ of energy and MP requirements, for an estimated intake of $25 \mathrm{~kg} / \mathrm{d}$ and milk production of $40 \mathrm{~kg} / \mathrm{d}, 3.85 \%$ fat, and $3.2 \% \mathrm{CP}$ (NRC, 2001). Prepartum and postpartum, cows were fed diets ad libitum. Postpartum, the daily allowance of TMR was offered in equal meals every even hour from automated feeders (Ankom, Fairport, NY). In addition to TMR, long hay was offered once a day to prevent ruminal disturbances: ad libitum from prepartum through 2 DIM, $2 \mathrm{~kg} / \mathrm{d}$ (as fed) from 3 to 6 DIM, and $1 \mathrm{~kg} / \mathrm{d}$ for the remainder of the study. The cows had free access to water and were housed in a tiestall barn. Feed offered and refused was weighed daily. Cows were milked twice daily (0800 and $2000 \mathrm{~h}$ ) and yield was recorded at each milking. Milk samples were collected for $3 \mathrm{~d}$ around each blood sampling day. The experimental protocol was approved by the Institutional Committee for Animal Care of the Sherbrooke Research Centre, and animals were cared for in accordance with the guidelines of the Canadian Council on Animal Care (2009).

Cows were blocked according to parity (second and third or greater) and were assigned to 1 of 2 treatments according to a generalized randomized incomplete block design with repeated measurements in time. The 2 treatments consisted of a continuous abomasal infusion $(8.05 \mathrm{~kg} / \mathrm{d})$ through a tube installed via the rumen cannula. The treatments were (1) continuous abomasal infusion of water (CTRL; $\mathrm{n}=4$ ) or (2) a mixture of free AA with casein profile (AA-CN; $\mathrm{n}=5$ ), initiated on the day of parturition (DIM 1). The rates of infusion, preparation of the AA solutions, and AA composition of the infusate are detailed in the companion paper (Larsen et al., 2015).

\section{Blood Sampling and Labeled Glucose Infusion}

Days of sampling were planned at 5, 15, and 29 DIM. On each of these days, $\mathrm{D}\left[6,6-^{2} \mathrm{H}\right]$-glucose $[23.7 \mathrm{mmol} / \mathrm{h}$, 99 mol percent excess (mpe); Cambridge Isotope Laboratories, Andover, MA] was infused in a jugular vein, from 0900 to $1345 \mathrm{~h}$, to determine glucose WB-Ra and utilization across tissues. In addition, starting at 0930 
Table 1. Composition of the TMR fed pre- and postpartum

\begin{tabular}{lcc}
\hline Ingredient, g/kg of DM & Prepartum & Postpartum \\
\hline Grass hay & 405 & - \\
Corn silage & 302 & - \\
Beet sugar pulp & 81 & - \\
Soybean meal & 138 & 474 \\
Grass silage & - & 340 \\
Corn grain, ground & - & 103 \\
Canola meal & - & 21 \\
Corn gluten feed 60\% & - & 21 \\
Corn dried distillers grains & - & 14 \\
Soybean meal & 62 & - \\
Salt & - & 19 \\
Mineral and vitamin premix ${ }^{3,2}$ & 17.5 & 8 \\
Calcium salts of fatty acids & \\
Estimate from NRC (2001) & & 34.0 \\
NE, Mcal/d & 14.2 & 16.4 \\
CP, \% of DM & 39.5 & 36.1 \\
NDF, \% of DM & 27.0 & 23.2 \\
ADF, \% of DM & 1,075 & 2,129 \\
RDP, g/d & 626 & 1,352 \\
RUP, g/d & 1,153 & 2,365 \\
MP, g/d & 585 & 1,157 \\
From microbial protein & 511 & 1,108 \\
From undegraded feed & 57 & 100 \\
From endogenous origin &
\end{tabular}

${ }^{1}$ Prepartum premix containing (per kg): $67.9 \mathrm{~g}$ of Ca; $1.4 \mathrm{~g}$ of P; $2.01 \mathrm{~g}$ of $\mathrm{Mg} ; 174 \mathrm{mg}$ of $\mathrm{Zn} ; 28.6 \mathrm{mg}$ of $\mathrm{Cu} ; 92 \mathrm{mg}$ of $\mathrm{Mn} ; 0.84 \mathrm{mg}$ of Se; 9.21 $\mathrm{kIU}$ of vitamin A; $2.85 \mathrm{kIU}$ of vitamin D, and $334.8 \mathrm{IU}$ of vitamin E. ${ }^{2}$ Lactation premix containing (per $\mathrm{kg}$ ): $91.8 \mathrm{~g}$ of Ca; $47.9 \mathrm{~g}$ of P; 47.9 $\mathrm{g}$ of $\mathrm{Mg} ; 11.9 \mathrm{~g}$ of $\mathrm{K} ; 80.8 \mathrm{~g}$ of $\mathrm{Cl} ; 136.8 \mathrm{~g}$ of Na $282.7 \mathrm{~g}$ of salt; $15 \mathrm{~g}$ of $\mathrm{S} ; 1,946 \mathrm{mg}$ of Fe; $2,656 \mathrm{mg}$ of $\mathrm{Zn} ; 440 \mathrm{mg}$ of $\mathrm{Cu} ; 1,798 \mathrm{mg}$ of $\mathrm{Mn} ; 23$ $\mathrm{mg}$ of I; $19.50 \mathrm{mg}$ of Se; $441.6 \mathrm{kIU}$ of vitamin A; $56.6 \mathrm{kIU}$ of vitamin $\mathrm{D}$, and 2,630 IU of vitamin E.

${ }^{3}$ Megalac Low Odor (Church \& Dwight Co. Inc., Princeton, NJ). ${ }^{4}$ Calculated using the average intake observed during the study for the control treatment, with chemical composition of the feed ingredients reported in Table 2 .

$\mathrm{h}$ until the end of the blood sampling, para-aminohippurate (pAH; $12 \mathrm{~g} / \mathrm{h})$ was infused continuously into 1 mesenteric vein using a syringe pump to determine portal and splanchnic plasma flows by downstream dilution of pAH (Katz and Bergman, 1969). Starting at least 30 min after the initiation of pAH infusion, 6 blood samples were taken at 45-min intervals (1000, 1045, 1130, 1215, 1300, and $1345 \mathrm{~h}$ ), simultaneously from the arterial, portal, and hepatic vein catheters and immediately after from the mammary vein by venipuncture. Immediately after sampling, blood was transferred from the syringes to heparinized tubes and kept on ice before centrifugation at $1,800 \times g$ for 12 min. One gram of plasma was weighed and mixed with $200 \mu \mathrm{g}$ of a $\left[\mathrm{U}_{-}{ }^{13} \mathrm{C}\right]$ glucose solution $(16 \mathrm{~m}$; $; 98 \%$ mpe, Spectra Stable Isotopes Laboratories, Andover, MA) to determine the glucose concentration and isotopic enrichment (IE). The processed plasma was stored at $-80^{\circ} \mathrm{C}$ for further analyses. Before initiation of labeled glucose infusion, a blood sample from each sampling site was collected to determine the natural abundance of glucose. Plasma subsamples were also frozen as-is for analyses of other metabolites and kept at $-20^{\circ} \mathrm{C}$. Additional arterial samples were collected according to the same sampling schedule and transferred into tubes with EDTA for NEFA analyses. All analyses were performed on individual samples. Cows were weighed on the day after blood sampling at DIM 5, 15, and on 3 consecutive days after DIM 29.

\section{Laboratory Analyses}

Samples of feed ingredients were collected each week, pooled for the whole project for concentrates and by 4 -wk periods for the hay and the silage, ground through a 1-mm screen Wiley mill (standard model 4; Arthur H. Thomas, Philadelphia, PA), and analyzed for CP, $\mathrm{ADF}, \mathrm{NDF}$, lignin, acid detergent insoluble CP, neutral detergent insoluble $\mathrm{CP}$, ash, and lipid as described by Martineau et al. (2007; Table 2). Milk composition was analyzed for lactose using a diagnostic kit (Megazyme International Ireland Ltd., Bray, Co. Wicklow, Ireland; distributed by Xygen Diagnostics Inc., Burgessville, ON, Canada). Milk fat was analyzed using the RöseGottlieb method (ethyl ether, petroleum ether, and alcohol for fat extraction; AOAC International, 1995; method no. 905.2). Milk samples $(\mathrm{n}=6)$ were pooled per cow $\times$ sampling period for lactose and fat analyses (DIM 5, 15, and 29).

Table 2. Chemical composition of feed ingredients

\begin{tabular}{|c|c|c|c|c|c|c|c|c|c|}
\hline $\begin{array}{l}\text { Analysis, } \\
\% \text { of DM }\end{array}$ & $\begin{array}{l}\text { Grass } \\
\text { hay }\end{array}$ & $\begin{array}{l}\text { Corn } \\
\text { silage }\end{array}$ & $\begin{array}{l}\text { Beet sugar } \\
\text { pulp }\end{array}$ & $\begin{array}{l}\text { Soybean } \\
\text { meal }\end{array}$ & $\begin{array}{l}\text { Grass } \\
\text { silage }\end{array}$ & $\begin{array}{l}\text { Corn grain, } \\
\text { ground }\end{array}$ & $\begin{array}{c}\text { Canola } \\
\text { meal }\end{array}$ & $\begin{array}{l}\text { Corn gluten } \\
\text { feed }\end{array}$ & $\begin{array}{c}\text { Corn dried } \\
\text { distillers grains }\end{array}$ \\
\hline $\mathrm{CP}$ & 9.5 & 8.3 & 10.4 & 53.8 & 14.9 & 8.9 & 37.1 & 69.1 & 29.6 \\
\hline $\mathrm{ADF}$ & 35.2 & 20.8 & 26.7 & 6.2 & 39.3 & 3.8 & 30.6 & 9.7 & 19.4 \\
\hline $\mathrm{NDF}$ & 58.3 & 34.4 & 37.7 & 9.8 & 54.8 & 9.1 & 46.3 & 36.9 & 49.8 \\
\hline Lignin & 6.4 & 3.0 & 6.1 & 0.5 & 6.5 & 1.3 & 10.3 & 11.5 & 4.9 \\
\hline $\mathrm{ADICP}^{1}$ & 0.9 & 0.5 & 2.4 & 0.4 & 2.1 & 0.5 & 7.5 & 9.0 & 4.0 \\
\hline $\mathrm{NDICP}^{1}$ & 4.0 & 1.2 & 4.5 & 0.7 & 5.0 & 1.6 & 14.6 & 30.3 & 15.9 \\
\hline Ash & 6.5 & 3.6 & 7.7 & 6.4 & 8.3 & 1.3 & 7.2 & 2.1 & 6.3 \\
\hline Lipid & 2.5 & 3.0 & 1.2 & 1.1 & 4.3 & 3.8 & 3.8 & 2.1 & 14.9 \\
\hline
\end{tabular}

${ }^{1} \mathrm{ADICP}=$ acid detergent insoluble crude protein; NDICP $=$ neutral detergent insoluble crude protein. 
The concentrations and IE of glucose were analyzed as described previously (Galindo et al., 2011). Plasma samples were analyzed for L-lactate using L-lactate oxidase (YSI 7100, YSI Inc., Yellow Springs, OH), and BHBA, glycerol, and NEFA concentrations using a Cobas Mira autoanalyzer (Triolab A/S, Brøndby, Denmark) and enzymatic kits based on D-3-hydroxybutyrate dehydrogenase, glycerol kinase/glycerol 3-phosphate dehydrogenase, and acyl CoA synthetase/acyl CoA oxidase, respectively (cat. nos. RB 1008, GY 105, and FA 115, respectively; Randox Laboratories Ltd., Crumlin, UK).

As described in the companion paper (Larsen et al., 2015), portal and splanchnic plasma flows were calculated by downstream dilution of pAH (Katz and Bergman, 1969); concentration of pAH was determined after deacetylation of pAH by heating the samples at $90^{\circ} \mathrm{C}$ for $2 \mathrm{~h}$ in acidic conditions as described by Lobley et al. (1995). Mammary plasma flow was estimated according to the Fick principle, using Phe and Tyr as internal markers (Cant et al., 1993), with an allowance for a $3.37 \%$ contribution from blood-derived proteins. Concentrations of Phe and Tyr in milk protein synthesized in the mammary gland (MG) were estimated at 51.9 and $58.7 \mathrm{~g} / \mathrm{kg}$ of true protein (Lapierre et al., 2012).

\section{Calculations and Statistical Analyses}

The ECM yield was calculated according to Sjaunja et al. (1991) using protein content reported in the companion paper (Larsen et al., 2015). The WB-Ra of glucose, net portal, splanchnic, hepatic, and mammary fluxes of nutrients, as well as the PDV, splanchnic, hepatic, and MG utilization of glucose from arterial plasma supply (PU) were calculated as described by Galindo et al. (2011). A positive flux indicates a release of the nutrient, whereas a negative net flux indicates removal by the tissue.

Data were analyzed with a mixed model including the fixed effects of parity, treatment (Trt), DIM, and the interaction Trt $\times$ DIM; DIM was tested as repeated measurement using autoregressive order 1 covariance structure with the Mixed procedure of SAS (SAS Institute, 2008). Denominator degrees of freedom were calculated using the Kenward-Rogers method. Results were expressed as least squares means with standard errors of means. Fisher's protected least significant difference (LSD) test was used to separate treatment means $(\mathrm{df}=6)$ within DIM in case of Trt $\times$ DIM interaction $(P \leq 0.20)$, using the Slice option in SAS. Significance was declared at $P \leq 0.10$ with a tendency at $0.10<P \leq 0.20$, because of the limited statistical power to test a treatment effect in randomized designs (needed in transition cow studies) with limited repetitions (number of splanchnic surgeries was limited due to technical and ethical constraints).

\section{RESULTS}

\section{Milk Production and $\mathrm{NE}_{L}$ Balance}

The ECM yield was greater with AA-CN $\left(P_{\text {Trt }}=\right.$ 0.04; Table 3) on the 3 sampling days and tended to increase with DIM $\left(P_{\mathrm{DIM}}=0.15\right)$ reflecting the opposing effects of concomitant increasing milk yield and decreasing fat and protein contents of milk with increasing DIM. Lactose yield increased $\left(P_{\text {Trt }}=0.01\right)$ and fat yield tended to increase $\left(P_{\mathrm{Trt}}=0.15\right)$ with AA-CN, whereas we detected a tendency for an interaction Trt $\times \operatorname{DIM}\left(P_{\text {Trt } \times \text { DIM }}=0.15\right)$ on lactose and fat concentrations, which tended to be lower for the AA-CN treatment on DIM 5 and 29, respectively. Lactose yield and concentration increased as lactation progressed $\left(P_{\mathrm{DIM}}\right.$ $<0.01)$. Body weight was not affected $\left(P_{\text {Trt }}=0.46\right)$ by treatments and there was no interaction of Trt $\times$ DIM $\left(P_{\text {Trt } \times \text { DIM }}=0.55\right)$.

Reflecting DMI, we found a tendency for a Trt $\times$ DIM interaction $\left(P_{\text {Trt }} \times\right.$ DIM $=0.13$; Table 3$)$ on $\mathrm{NE}_{\mathrm{L}}$ supply from the diet, with this supply being numerically lower at DIM 5 and tending to be higher $(P=0.18)$ on DIM 29 for AA-CN cows. However, when the infusion of AA was taken into account, similar numerical trends between Trt were observed but the interaction was not significant $\left(P_{\mathrm{Trt}} \times\right.$ DIM $\left.=0.21\right)$. The $\mathrm{NE}_{\mathrm{L}}$ balance was affected differently by AA infusion with DIM $\left(P_{\text {Trt } \times \text { DIM }}\right.$ $=0.10)$, with the AA-CN cows having a lower $(P=$ 0.05) $\mathrm{NE}_{\mathrm{L}}$ balance on DIM 5, tending to have a lower $(P=0.16) \mathrm{NE}_{\mathrm{L}}$ on DIM 15 , but with no difference $(P$ $=0.70)$ between AA-CN and CTRL cows on DIM 29 .

\section{Arterial Concentrations and Net Flux of Nutrients}

Arterial concentrations of glucose and lactate were not affected by AA-CN $\left(P_{\text {Trt }} \geq 0.48\right.$; Table 4$)$. Arterial glucose concentration increased and arterial lactate concentration decreased as lactation progressed $\left(P_{\mathrm{DIM}}\right.$ $\leq 0.01$. Arterial concentrations of BHBA, glycerol, and NEFA were greater $(P<0.10)$ at 5 DIM for AACN compared with CTRL, but did not differ by 29 $\operatorname{DIM}\left(P_{\text {Trt }} \times\right.$ DIM $\left.\leq 0.10\right)$.

The net portal flux of glucose tended to increase with AA-CN $\left(P_{\text {Trt }}=0.18\right.$; Table 5$)$, whereas neither net hepatic release nor net splanchnic release was altered $\left(P_{\mathrm{Trt}} \geq 0.77\right)$ by AA-CN. Net splanchnic release of glucose increased with increasing DIM $\left(P_{\mathrm{DIM}}=0.06\right)$. The net mammary uptake (negative net flux) of glucose 
increased for AA-CN $\left(P_{\mathrm{Trt}}=0.07\right)$ and with progressing lactation $\left(P_{\mathrm{DIM}}=0.02\right)$.

The portal, hepatic, splanchnic, and mammary net fluxes of lactate were not affected by AA-CN $\left(P_{\mathrm{Trt}} \geq\right.$ 0.24 ; Table 5$)$. The relative contribution of net portal appearance to net hepatic removal of lactate was lower, however, in AA-CN than in CTRL cows $\left(P_{\operatorname{Trt}}\right.$ $=0.05$ ), with this difference (between AA-CN and CTRL $)$ being higher at DIM $15\left(P_{\text {Trt }} \times\right.$ DIM $=0.13$; Table 6). Also, the net portal appearance of lactate increased $\left(P_{\text {DIM }}<0.01\right)$ as lactation progressed for both AA-CN and CTRL cows, so that the contribution of portal appearance to net hepatic removal increased from 5 to 29 DIM $\left(P_{\mathrm{DIM}}<0.01\right)$. Overall, net splanchnic removal of lactate decreased as lactation progressed $\left(P_{\text {DIM }}=0.03\right)$, as did the maximal contribution of lactate removal to net hepatic glucose release $\left(P_{\text {DIM }}=0.05\right.$; Table 6$)$.

Net fluxes of BHBA across splanchnic and mammary tissues were not affected by AA infusion $\left(P_{\mathrm{Trt}} \geq 0.22\right.$; Table 5). Both net portal release and net mammary uptake of BHBA increased as DIM progressed $\left(P_{\text {DIM }}\right.$ $=0.02)$. Net fluxes of glycerol across splanchnic and mammary tissues tended to be affected differently by AA infusion across sampling days $\left(P_{\text {Trt }} \times\right.$ DIM $\leq 0.20$; Table 5). At 5 DIM, the net hepatic, splanchnic, and mammary removals of glycerol were higher or tended to be higher $(P<0.20)$ for AA-CN compared with CTRL, whereas they did not differ at DIM 29. The contribution of net portal appearance to net liver removal of glycerol decreased as lactation progressed $\left(P_{\text {DIM }}=0.10\right)$ as did the maximal contribution of hepatic removal of glycerol to net release of glucose $\left(P_{\text {DIM }}<0.01\right.$; Table 6$)$.

\section{Whole-Body and Tissue Glucose Kinetics}

The arterial, portal, hepatic, and mammary IE of glucose tended ( $P_{\text {Trt }} \leq 0.17$; Table 7$)$ to decrease with AA-CN infusion and decreased as lactation progressed $\left(P_{\text {DIM }} \leq 0.13\right)$. Accordingly, the WB-Ra of glucose tended to increase with AA-CN $\left(P_{\text {Trt }}=0.18\right)$, and increased $\left(P_{\text {DIM }}=0.06\right)$ as lactation advanced.

Although portal and hepatic utilization of glucose from arterial supply were not affected $\left(P_{\text {Trt }} \geq 0.23\right.$; Table 7) by AA infusion, splanchnic utilization of glucose tended $\left(P_{\text {Trt }} \leq 0.14\right)$ to increase in AA-CN cows. As observed for net MG uptake, MG utilization of glucose was higher $\left(P_{\text {Trt }}=0.03\right)$ in AA-CN than CTRL cows and increased for both treatments as lactation progressed $\left(P_{\mathrm{DIM}}=0.02\right)$. The proportions of $\mathrm{PDV}_{\mathrm{PU}}$, $\mathrm{HEP}_{\mathrm{PU}}, \mathrm{TSP}_{\mathrm{PU}}$, and $\mathrm{MG}_{\mathrm{PU}}$ (where $\mathrm{PU}=$ utilization from plasma supply, HEP = hepatic, and TSP $=$ total splanchnic tissue) relative to WB-Ra were not altered by AA-CN infusion or DIM $(P \geq 0.21)$. 
Table 4. Effects of abomasal infusion of AA in postpartum transition dairy cows on arterial concentration $(\mathrm{m} M)$ of $^{\text {metabolites }}{ }^{1}$

\begin{tabular}{|c|c|c|c|c|c|c|c|c|c|c|}
\hline Metabolite & \multicolumn{2}{|c|}{5 DIM } & \multicolumn{2}{|c|}{15 DIM } & \multicolumn{2}{|c|}{29 DIM } & SEM & \multicolumn{3}{|c|}{$P$-value ${ }^{2}$} \\
\hline Glucose & 3.15 & 3.00 & 3.03 & 2.96 & 3.26 & 3.28 & 0.18 & 0.72 & $<0.01$ & 0.52 \\
\hline BHBA & 0.66 & $1.26^{*}$ & 0.97 & $1.29 \dagger$ & 0.86 & 0.88 & 0.19 & $<0.01$ & 0.02 & 0.03 \\
\hline Glycerol & 0.029 & $0.044^{*}$ & 0.022 & 0.028 & 0.020 & 0.017 & 0.005 & 0.16 & $<0.01$ & 0.10 \\
\hline NEFA & 0.38 & $0.72^{*}$ & 0.39 & 0.39 & 0.34 & 0.25 & 0.07 & 0.40 & 0.01 & 0.05 \\
\hline
\end{tabular}

${ }^{1}$ Treatments (Trt) were continuous abomasal infusion of water (CTRL) or a mixture of free AA with casein profile (AA-CN) from 1 to 29 DIM; LSM with SEM given for $\mathrm{n}=4$.

${ }^{2}$ Probability corresponding to the null hypothesis.

$* P \leq 0.10, \dagger P \leq 0.20$ : difference between LSM within DIM and rows when interaction $P_{\text {Trt }} \times$ DIM $\leq 0.20$.

The portal true flux of glucose was higher in AACN than in CTRL cows $\left(P_{\text {Trt }}<0.01\right.$; Table 7$)$ and increased as lactation advanced $\left(P_{\mathrm{DIM}}=0.09\right)$, whereas true hepatic and splanchnic fluxes were unaffected by AA-CN infusion $\left(P_{\operatorname{Trt}} \geq 0.70\right)$. On average, the true portal and hepatic glucose fluxes contributed 15 and $87 \%$ of WB-Ra, respectively.

The MG was the major user of glucose, with total utilization averaging $77 \%$ of WB-Ra. The ratios of milk lactose yield to WB-Ra, milk lactose yield to net mammary glucose uptake, and milk lactose yield to splanchnic true flux were not affected by AA-CN $\left(P_{\text {Trt }} \geq 0.25\right.$; Table 7 ), but the ratio of lactose to glucose WB-Ra increased as lactation advanced $\left(P_{\mathrm{Trt}}=0.04\right)$.

\section{DISCUSSION}

\section{Whole-Body Rate of Appearance of Glucose}

In the lactating cow, the demand for glucose is important, both as an energy source and as the major contributor to mammary lactose synthesis (Bickerstaffe et al., 1974). However, even in dairy cows fed concentrate diets, absorption of glucose would represent maximally $25 \%$ of total glucose availability, the remainder originating mainly from hepatic synthesis (Galindo et al., 2011), with the major glucose precursors including propionate, lactate, AA, and glycerol (Young, 1977). The WB-Ra of glucose represents the sum of glucose

Table 5. Effects of abomasal infusion of AA in postpartum transition dairy cows on net flux ${ }^{1}$ of metabolites ${ }^{2}$

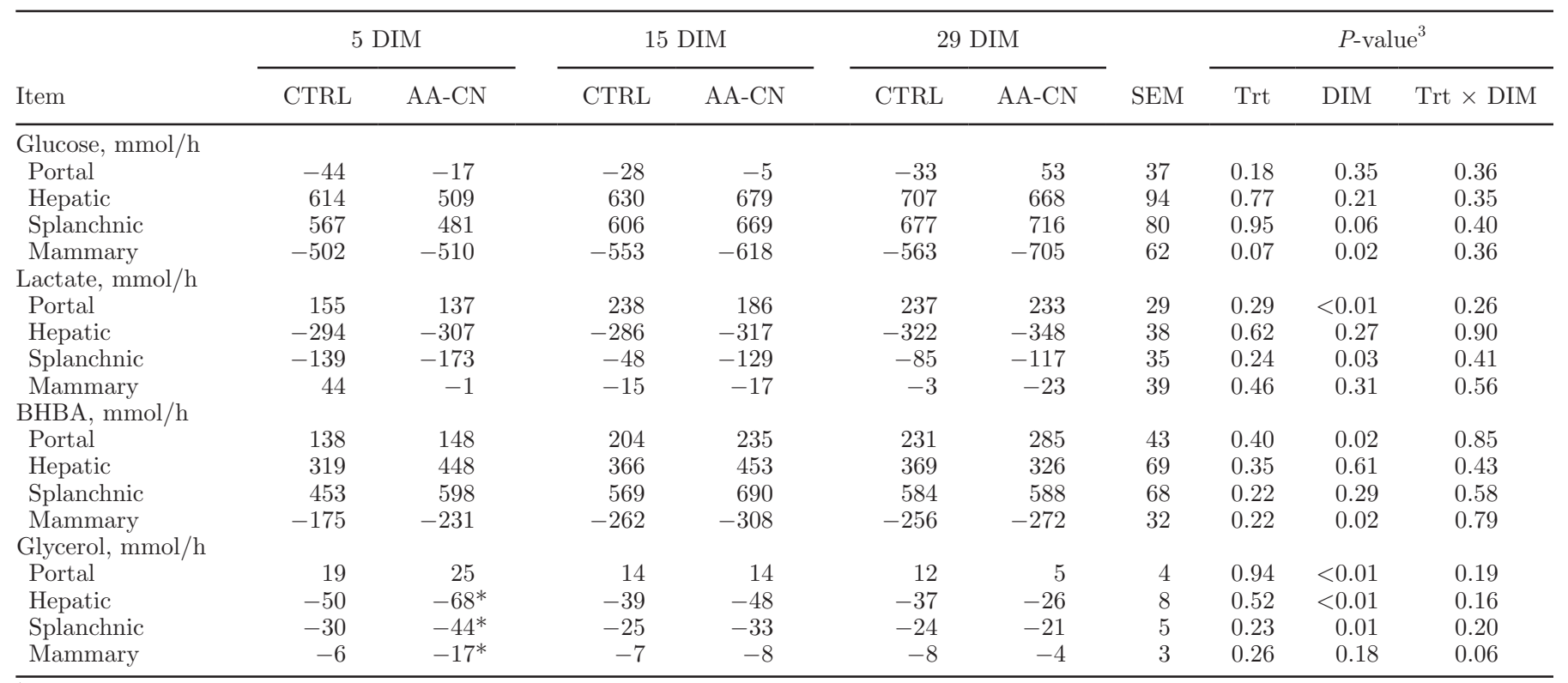

${ }^{1} \mathrm{~A}$ positive flux indicates a release and negative flux indicates an uptake by the tissue.

${ }^{2}$ Treatments (Trt) were continuous abomasal infusion of water (CTRL) or a mixture of free AA with casein profile (AA-CN) from 1 to 29 DIM; LSM with SEM given for $n=4$.

${ }^{3}$ Probability corresponding to the null hypothesis.

${ }^{*} P \leq 0.10$ : difference between LSM within DIM and rows when interaction $P_{\mathrm{Trt}} \times$ DIM $\leq 0.20$. 


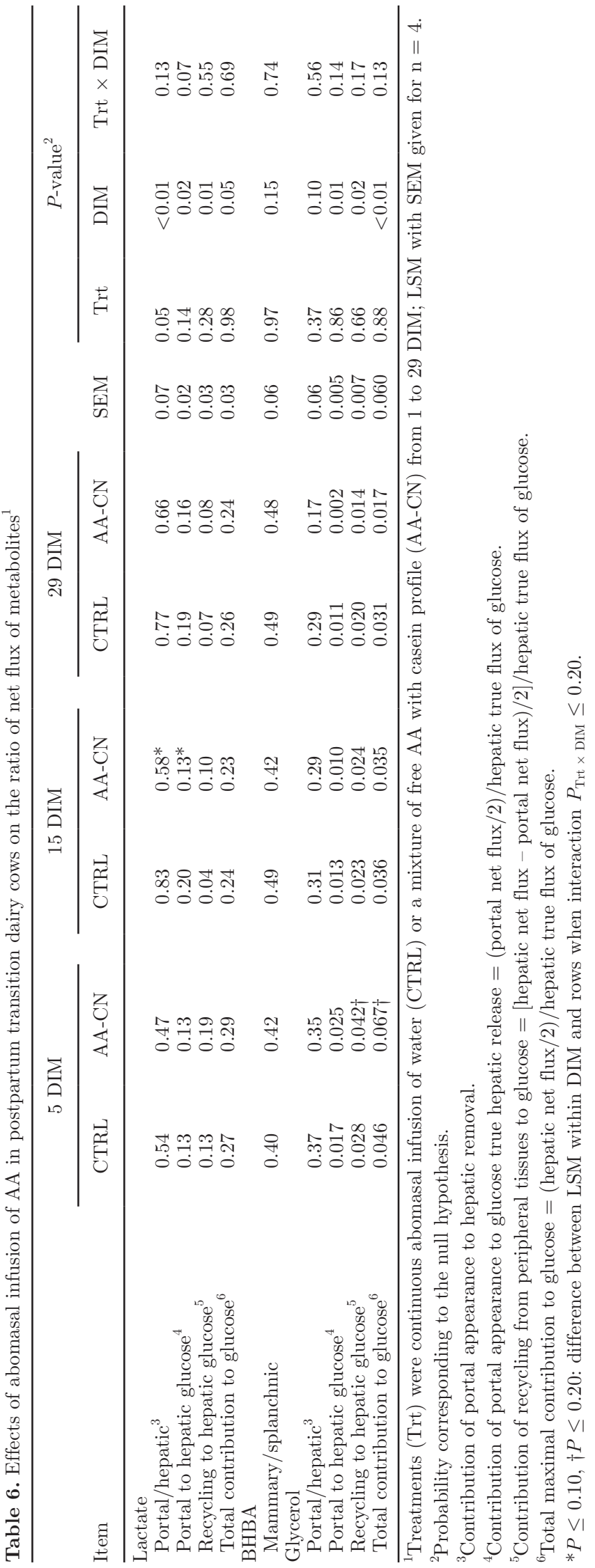

synthesis, glucose absorption, and glycogenolysis: in this context, glucose synthesis represents total glucose production and therefore includes synthesis from recycled glucose carbons.

In the current study, with cows enrolled immediately after calving, WB-Ra of glucose tended to increase with AA-CN. A rough estimate of the maximal direct contribution of the incremental AA supply to glucose WB-Ra has been calculated using the difference between MP supply minus the increment in milk true protein yield at each DIM in the AA-CN compared with the CTRL cows; the casein composition has then been attributed to this difference and we assumed that it takes 2 moles of AA to synthesize 1 mole of glucose. The increased glucose WB-Ra in AA-CN compared with CTRL cows was twice the maximal conversion into glucose of the extra supply of AA not used to support the increment in milk true protein yield, this excess averaging 185, 196 , and $285 \mathrm{~g} / \mathrm{d}$ at DIM 5, 15, and 29, respectively. The extra supply of AA with AA-CN treatment has been calculated taking into account both the infusion of AA and variations in dietary MP supply (Larsen et al., 2015). In studies conducted in cows later in lactation, infusion of casein or free AA with casein profile increased WB-Ra of glucose (e.g., Clark et al., 1977; Lemosquet et al., 2009; Galindo et al., 2011) with a calculated efficiency of transfer of infused AA not used to support the increment in milk protein secretion into glucose close to the maximal theoretical efficiency of 100\% (Lapierre et al., 2010). This indicates that during the transition period, glucose synthesis is regulated by more than just precursor supply. Indeed, glucose WB-Ra increased by more than 70\% (from 343 to 593 $\mathrm{mmol} / \mathrm{h}$ ) from $\mathrm{d}-30$ to $\mathrm{d}+40$ around parturition in cows with similar diet and DMI (Bennink et al., 1972). In cows fed ad libitum, from 2 wk before to 5 wk after parturition, DMI increased by $26 \%$, from 14.8 to $18.7 \mathrm{~kg} / \mathrm{d}$, whereas splanchnic net release of glucose increased by $45 \%$, from 486 to $703 \mathrm{mmol} / \mathrm{h}$, with approximately $30 \%$ of this increase resulting from increased portal absorption and the remainder, 70\%, from hepatic glucose release (Doepel et al., 2009).

Therefore, to better understand the mechanisms underlying the variations observed in WB-Ra of glucose, we examined glucose kinetics and net fluxes of energyyielding nutrients across tissues.

\section{Portal-Drained Viscera Metabolism}

Glucose utilization by all individual tissues should sum to the glucose rate of disappearance at the WB level (WB-Rd), which at equilibrium equals WB-Ra. In tissues such as the PDV and liver, the net flux measurement includes simultaneous release and uptake of 
Table 7. Effects of abomasal infusion of AA in postpartum transition dairy cows on glucose kinetics at whole-body level and across splanchnic and mammary tissues ${ }^{1}$

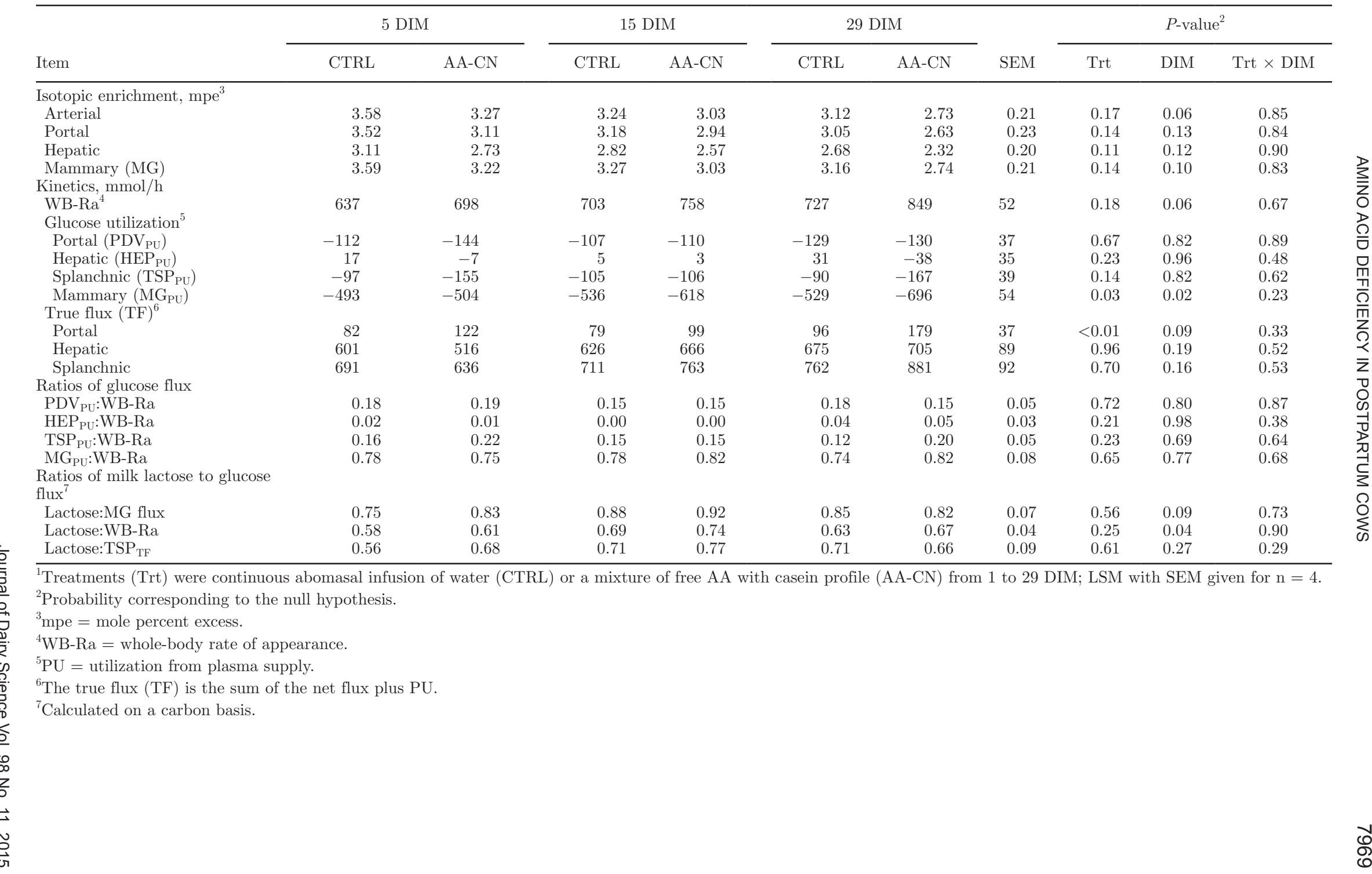


glucose by a tissue. Consequently, for these tissues, their true release of glucose is calculated as the sum of the net flux plus utilization from arterial plasma supply.

Through digestion of starch and subsequent release of glucose into portal circulation, the PDV contribute to WB-Ra of glucose. Indeed, although PDV glucose net flux was only positive for the AA-CN cows at DIM 29, calculation of the true PDV flux of glucose indicates that the PDV contributed to $13 \%$ of the WB-Ra in CTRL cows and $17 \%$ in AA-CN cows. The true portal absorption of glucose averaged 31 and $52 \%$ of the estimated rumen starch escape (Offner and Sauvant, 2004; INRA, 2007) for CTRL and AA-CN treatments, respectively. Loncke et al. (2009) reported that, on average, $43 \%$ of the starch digested was recovered into net portal absorption of glucose. As glucose utilization from arterial supply by the PDV did not decrease with AA infusion, one hypothesis to explain the increased true portal glucose flux might be that the AA-CN infusion stimulated the secretion of pancreatic $\alpha$-amylase (Richards et al., 2003; Swanson et al., 2004), thereby enhancing the digestion of starch (Abramson et al., 2002, 2005). Another possibility would be a sparing effect of enteral glucose oxidation with increased AA supply. In rats, Asp, Gln, and Glu from the lumen contributed 39\% of $\mathrm{CO}_{2}$ production, and arterial Gln contributed $38 \%$ of $\mathrm{CO}_{2}$ production (Windmueller and Spaeth, 1980). In pigs, high protein feeding reduced glucose enteral oxidation compared with a low protein feeding (Van der Schoor et al., 2001). Indeed, in the current study, observations would indicate increased catabolism of the branched-chain AA by the PDV (Larsen et al., 2015). However, in ruminants, infusion of casein in sheep (ElKadi et al., 2006) or of Gln (Doepel et al., 2007) or of casein or AA in dairy cows (Galindo et al., 2011) did not alter net portal flux of glucose. As the current study was not designed to analyze the use of glucose from luminal supply, we cannot determine whether, in the immediate postpartum period, the enterocytes of the AA-CN cows utilized less glucose from intestinal lumen digestion, thereby increasing the contribution of portal true flux to WB-Ra of glucose. It would be interesting to investigate whether the positive effect of increased AA supply on glucose kinetics in postpartum dairy cows is affected by the level of starch escaping the rumen. This could indicate if increased availability of glucose via PDV metabolism is a prerequisite for the great effect of postpartum MP supply on milk production, but would not delineate which mechanism is responsible for the increased true flux of glucose.

Utilization of glucose from arterial supply by the PDV was not altered by AA-CN infusion in the current study. This supports previous observations where increased AA supply did not alter glucose utilization from arterial supply by the PDV in ruminants (El-Kadi et al., 2006; Galindo et al., 2011). The relative contribution of the PDV to WB-Rd of glucose is similar to the $15 \%$ value observed when cows were fed a protein-deficient diet (Galindo et al., 2011). This ratio decreased to $10.6 \%$ when cows received an adequate supply of AA (Galindo et al., 2011), supporting the protein deficiency encountered in early lactation, MP balance being still numerically negative at DIM 29 (Larsen et al., 2015) for both treatments. In growing ruminants, the relative contribution of PDV utilization of glucose to WB-Rd was more important, although it fluctuated widely in sheep from 6 to $25 \%$ of WB-Rd (Bergman et al., 1970; Huntington et al., 1980; Majdoub et al., 2003) and in steers between 11 and 34\% of WB-Rd (Seal and Parker, 1994; Harmon et al., 2001).

Net portal fluxes of lactate and BHBA increased as lactation progressed, in agreement with previous observations in periparturient dairy cows (Reynolds et al., 2003; Raun and Kristensen 2011), with no effect of AACN infusion. Larsen and Kristensen (2009) and Raun and Kristensen (2011) suggested that the portal net fluxes of lactate and BHBA were primarily related to feed intake in the immediate postpartum period, which would agree with our observations.

\section{Hepatic and Splanchnic Metabolism}

Hepatic true release of glucose was not affected by AA-CN infusion and represented, on average, $87 \%$ of WB-Ra of glucose. Galindo et al. (2011) reported that, in lactating dairy cows (77 \pm 13 DIM), increased supply of AA elevated the hepatic release of glucose, with the effect on WB-Ra induced by protein supply originating mainly from liver glucose synthesis. The current observations indicate that in the immediate postpartum period, increased AA supply has a very limited effect on gluconeogenesis, whereas in previous studies with cows after the peak of lactation (e.g., Hanigan et al., 2004; Galindo et al., 2011), increased AA supply increased net hepatic release of glucose. Variation occurring with stage of lactation in the contribution of glucogenic precursors to gluconeogenesis may be related to mRNA expression of 2 enzymes, pyruvate carboxylase (PC) and phophoenolpyruvate carboxykinase (PEPCK), regulating the entry of pyruvate and oxaloacetate to either the citric acid cycle or gluconeogenesis in liver tissues (Aschenbach et al., 2010; Loor, 2010). The mRNA expression of PC in liver tissue increases rapidly in the immediate postpartum period, whereas PEPCK mRNA increases slowly during the first $4 \mathrm{wk}$ of lactation (Greenfield et al., 2000; Agca et al., 2002; Loor, 2010). The increase in PC mRNA and activity immediately postpartum will increase oxa- 
loacetate formation from pyruvate, oxaloacetate being the initial precursor pool for both gluconeogenesis and citric acid cycle (Aschenbach et al., 2010). Therefore, greater availability of oxaloacetate will activate both gluconeogenesis and the citric acid cycle, with increased entry of acetyl CoA from mobilized fatty acids. This larger entry of pyruvate to the citric acid cycle will require more lactate and several glucogenic AA, the most important being Ala (Aschenbach et al., 2010; Larsen and Kristensen, 2013). Therefore, increased PC expression plays a key role in promoting the entry of endogenous precursors, such as lactate, in gluconeogenesis at the initiation of lactation when intake is compromised, whereas PEPCK expression would preferably control gluconeogenesis when feed intake is not constrained (Aschenbach et al., 2010). These observations could explain in part why AA supply did not increase hepatic gluconeogenesis in periparturient dairy cows, contrary to what has been reported in cows with established lactation (Galindo et al., 2011).

Indeed, during fasting simulating negative energy balance, the contribution from endogenous glucogenic precursors such as glycerol and lactate increased (Lomax and Baird, 1983). In the current study, although liver removal of lactate remained unchanged with AA-CN infusion, the contribution of portal net flux to hepatic removal of lactate decreased with AA-CN infusion, indicating a proportionally greater recycling of lactate from peripheral tissues to hepatic removal with AA-CN. Also, the contribution of recycling of lactate and glycerol from peripheral tissues to hepatic removal decreased as lactation progressed, indicating the important inter-organ transfer of glucogenic carbons from lactate and glycerol from peripheral tissues at the initiation of lactation to support the increased glucose demand (Larsen and Kristensen, 2013).

Although the abomasal infusion of AA-CN did not increase net or true hepatic and splanchnic releases of glucose, the numerical increment between splanchnic true flux and WB-Ra induced by AA-CN infusion was of similar magnitude at 15 and 29 DIM, but not at 5 DIM. This might indicate that in the very early postpartum period, AA-CN infusion increased WB-Ra of glucose from postsplanchnic metabolism, by either increased gluconeogenesis from the kidneys or increased glycogenolysis from peripheral tissues. Indeed, the AA$\mathrm{CN}$ treatment at 5 DIM was the only sampling time where true splanchnic flux of glucose did not account for all of the observed WB-Ra of glucose. It should be pointed out that, although cows were in negative energy balance throughout the experiment, it was only at 5 DIM that the $\mathrm{NE}_{\mathrm{L}}$ balance was significantly lower for the AA-CN treatment compared with the CTRL.
Glucose utilization from plasma supply by the liver was minimal (not different from zero), as previously reported in ruminants (Bergman et al., 1970). This is supported by the fact that the liver does not have the ability to phosphorylate glucose, which can thus not enter the glycolytic pathway. Therefore, net flux and true flux of glucose across the liver were almost identical.

During periods of negative energy balance, adipocytes release NEFA into blood circulation, produced by hydrolysis of triacylglycerols (Vernon, 2003). The NEFA taken up by the liver are either oxidized to $\mathrm{CO}_{2}$ or converted to ketone bodies, which are released for use in the body, or esterified to fatty acids to triacylglycerols and phospholipids (Vernon, 2002). In the current study, arterial concentrations of NEFA were higher at DIM 5 and increased to a greater extent in AA-CN cows. The abrupt increase in plasma NEFA concentrations at calving is a common observation (e.g., Drackley, 1999; Doepel et al., 2006). The higher increment in AA-CN cows indicates that lipid mobilization immediately postpartum was probably greater for these cows as further supported by greater hepatic and mammary glycerol uptake at 5 DIM. This assumes that these tissues were the only organs utilizing glycerol and that all circulating glycerol originates from hydrolysis of adipocyte triacylglycerols. These observations are also in line with the fact that despite the AA-CN cows being infused at a higher rate at DIM 5 than DIM 29, they had a lower DMI and $\mathrm{NE}_{\mathrm{L}}$ balance than the CTRL cows at DIM 5.

Arterial concentrations of BHBA increased with AACN infusion at DIM 5 but not at DIM 29, in line with the higher NEFA concentrations. Portal net appearance of BHBA averaged less than half of hepatic release at DIM 5 and increased as lactation progressed to be approximately equivalent to it at DIM 29 for the AACN cows. Liver release of BHBA could be supported by liver uptake of NEFA and the limited capacity of the liver for oxidation (Emery et al., 1992), allowing the formation of ketone bodies (acetoacetate and BHBA) that could be used as energetic sources for fatty acid synthesis by the mammary gland.

\section{Milk, Lactose, and Fat Yields and Mammary Metabolism}

Energy-corrected milk and lactose yields drastically increased with AA-CN infusion, as previously reported for postpartum cows under a similar infusion scheme (casein rather than free AA; Larsen et al., 2014). In contrast, infusion of glucose during the same close postpartum period decreased DMI and milk yield (Larsen and Kristensen, 2009). Ørskov et al. (1977) reported 
similarly that, for cows in early lactation and negative energy balance, glucose infusion was ineffective in increasing milk yield, whereas casein infusion increased milk production by $27 \%$.

The MG, depending on the physiological stage of the cow, may catabolize excess substrates and coordinate the flux of their carbon skeletons toward pathways that lead to synthesis of those nutrients not extracted in sufficient amounts (Bequette et al., 2006). The MG was the major user of glucose, with the net glucose uptake representing $77 \%$ of WB-Rd, a proportion in the range of that observed with limited protein supply for latelactation dairy cows (Lemosquet et al., 2009; Galindo et al., 2011). In line with the increased lactose secretion in AA-CN cows, mammary glucose net flux and utilization were higher in AA-CN than in CTRL cows, but the ratio of MG uptake relative to WB-Ra was not affected by treatments. However, these proportions were slightly higher than previously reported for latelactation cows (Lemosquet et al., 2009; Galindo et al., 2011). Similarly, the proportion of lactose output relative to WB-Ra, averaging $65 \%$ and only numerically increased by AA-CN treatment, was slightly higher than values reported in these previous 2 studies, with average values of 50 and $53 \%$, respectively. Together, these data indicate a shortage of glucose in very early lactation, as a greater proportion of glucose available was taken by the MG and used for lactose synthesis (assuming all lactose originating from glucose) than in cows with established lactation. Yet, increasing early postpartum glucose supply has failed to increase milk production as discussed earlier.

Although we detected no interaction of Trt $\times$ DIM on fat yield, the tendency for the effect of treatment was largely driven by the increment observed at DIM 5 . On that day, the increment in fat yield may be associated with the lower $\mathrm{NE}_{\mathrm{L}}$ balance for the AA-CN treatment, resulting in greater fat mobilization, as indicated by the higher NEFA concentrations. The contribution of preformed FFA, from NEFA or from triglycerides, to the long-chain FA of milk fat (Lemosquet et al., 2009) was not measured in the current study and was likely the source of extra carbons needed to support this increased fat yield.

\section{CONCLUSIONS}

The increased supply of AA in postpartum dairy cows tended to increase the WB-Ra of glucose without affecting the true liver glucose release. The WB-Ra of glucose response to increased AA supply in early lactation seemed to originate mainly from a greater true portal release of glucose, with PDV glucose utilization from arterial supply being unaffected. The exact mechanism responsible for the greater true PDV glucose release could not be assessed with the techniques used in the current study. These results indicate that in cows in early lactation, increased AA supply is not directed toward increased hepatic glucose synthesis, probably because of the very high anabolic demand for AA. Therefore, even under increased AA supply, glucogenic substrates such as lactate and glycerol and the mobilization of body fat would play an important role in this interval transition to support the energy demands.

\section{ACKNOWLEDGMENTS}

The authors express sincere appreciation to P. Dubreuil and M. Babkine (Faculty of Veterinary Medicine, University of Montreal, St-Hyacinthe, QC, Canada) and to R. Martineau (DSRDC, Agriculture and AgriFood Canada, Sherbrooke, QC, Canada) for surgical assistance and veterinary care of the animals. The authors thank the staff of the Dairy Centre for animal care during the experiment; and D. Bournival, M. Léonard, L. Marier, S. Méthot, and J. Renaud (DSRDC, Agriculture and Agri-Food Canada, Sherbrooke, QC, Canada), and A. Krustrup (Aarhus University, Foulum, Denmark) for technical assistance, laboratory analyses, and statistical advice. The authors acknowledge the financial support from the Canola Council of Canada (Winnipeg, MB, Canada), Agriculture and Agri-Food Canada and the Natural Sciences and Engineering Research Council of Canada (Ottawa, ON, Canada). The participation of M. Larsen was funded by The Danish Council for Technology and Innovation (Copenhagen, Denmark; \#10-080821) and by Aarhus University (Foulum, Denmark).

\section{REFERENCES}

Abramson, S. M., I. Bruckental, L. Lipshitz, U. Moalem, S. Zamwel, and A. Arieli. 2005. Starch digestion site: Influence of ruminal and abomasal starch infusion on starch digestion and utilization in dairy cows. Anim. Sci. 80:201-207.

Abramson, S. M., I. Bruckental, S. Zamwel, and A. Arieli. 2002. Effect of abomasally infused casein on postruminal digestibility of total non-structural carbohydrates and milk yield and composition in dairy cows. Anim. Sci. 74:347-355.

Agca, C., R. B. Greenfield, J. R. Hartwell, and S. S. Donkin. 2002. Cloning and characterization of bovine cytosolic and mitochondrial PEPCK during transition to lactation. Physiol. Genomics 11:53-63.

AOAC International. 1995. Official Methods of Analysis. 16th ed. AOAC International, Arlington, VA.

Aschenbach, J. R., N. B. Kristensen, S. S. Donkin, H. M. Hammon, and G. B. Penner. 2010. Gluconeogenesis in dairy cows: The secret of making sweet milk from sour dough. IUBMB Life 62:869-877.

Bell, A. W. 1995. Regulation of organic nutrient metabolism during transition from late pregnancy to early lactation. J. Anim. Sci. $73: 2804-2819$. 
Bennink, M. R., R. W. Mellenberger, R. A. Frobish, and D. E. Bauman. 1972. Glucose oxidation and entry rate as affected by the initiation of lactation. J. Dairy Sci. 55(Suppl. 1):712. (Abstr.)

Bequette, B. J., N. E. Sunny, S. W. El-Kadi, and S. L. Owens. 2006. Application of stable isotopes and mass isotopomer distribution analysis to the study of intermediary metabolism of nutrients. J. Anim. Sci. 84(E-Suppl.):E50-E59.

Bergman, E. N., M. L. Katz, and C. F. Kaufman. 1970. Quantitative aspects of hepatic and portal glucose metabolism and turnover in sheep. Am. J. Physiol. 219:785-793.

Bickerstaffe, R., E. F. Annison, and J. L. Linzell. 1974. The metabolism of glucose, acetate, lipids and amino acids in lactating dairy cows. J Agric. Sci. (Camb.) 82:71-85.

Canadian Council on Animal Care. 2009. Guide to the care and use of experimental animals. 2nd ed. Vol. 1. E. D. Rolfert, B. M. Cross, and A. A. McWilliam. Can. Counc. Anim. Care, Ottawa, ON, Canada.

Cant, J. P., E. J. DePeters, and R. L. Baldwin. 1993. Mammary amino acid utilization in dairy cows fed fat and its relationship to milk protein depression. J. Dairy Sci. 76:762-774.

Clark, J. H., H. R. Spires, R. G. Derrig, and M. R. Bennink. 1977. Milk production, nitrogen utilization and glucose synthesis in lactating cows infused postruminally with sodium caseinate and glucose. J. Nutr. 107:631-644.

Dalbach, K. F., M. Larsen, B. M. L. Raun, and N. B. Kristensen. 2011. Effects of supplementation with 2-hydroxy-4-(methylthio)butanoic acid isopropyl ester on splanchnic amino acid metabolism and essential amino acid mobilization in postpartum transition Holstein cows. J. Dairy Sci. 94:3913-3927.

Doepel, L., M. Lessard, N. Gagnon, G. E. Lobley, J. F. Bernier, P. Dubreuil, and H. Lapierre. 2006. Effect of postruminal glutamine supplementation on immune response and milk production in dairy cows. J. Dairy Sci. 89:3107-3121.

Doepel, L., G. E. Lobley, J. F. Bernier, P. Dubreuil, and H. Lapierre. 2007. Effect of glutamine supplementation on splanchnic metabolism in lactating dairy cows. J. Dairy Sci. 90:4325-4333.

Doepel, L., G. E. Lobley, J. F. Bernier, P. Dubreuil, and H. Lapierre. 2009. Differences in splanchnic metabolism between late gestation and early lactation dairy cows. J. Dairy Sci. 92:3233-3243.

Drackley, J. K. 1999. Biology of dairy cows during the transition period: The final frontier? J. Dairy Sci. 82:2259-2273.

Drackley, J. K., T. R. Overton, and G. N. Douglas. 2001. Adaptations of glucose and long-chain fatty acid metabolism in liver of dairy cows during the periparturient period. J. Dairy Sci. 84:E100-E112.

El-Kadi, S. W., R. L. Baldwin VI, N. E. Sunny, S. L. Owens, and B. J. Bequette. 2006. Intestinal protein supply alters amino acid, but not glucose, metabolism by the sheep gastrointestinal tract. J. Nutr. 136:1261-1269.

Emery, R. S., J. S. Liesman, and T. H. Herdt. 1992. Metabolism of long chain fatty acids by ruminant liver. J. Nutr. 122:832-837.

Galindo, C. E., D. R. Ouellet, D. Pellerin, S. Lemosquet, I. OrtiguesMarty, and H. Lapierre. 2011. Effect of amino acid or casein supply on whole-body, splanchnic and mammary glucose kinetics in lactating dairy cows. J. Dairy Sci. 94:5558-5568.

Greenfield, R. B., M. J. Cecava, and S. S. Donkin. 2000. Changes in mRNA expression for gluconeogenic enzymes in liver of dairy cattle during the transition to lactation. J. Dairy Sci. 83:1228-1236.

Grummer, R. R. 1995. Impact of changes in organic nutrient metabolism on feeding the transition dairy cow. J. Anim. Sci. 73:28202833.

Hanigan, M. D., C. K. Reynolds, D. J. Humphries, B. Lupoli, and J. D. Sutton. 2004. A model of net amino acid absorption and utilization by the portal-drained viscera of the lactating dairy cow. J. Dairy Sci. 87:4247-4268.

Harmon, D. L., C. J. Richards, K. C. Swanson, J. A. Howell, J. C. Matthews, A. D. True, G. B. Huntington, S. A. Gahr, and R. W. Russel. 2001. Influence of ruminal or postruminal starch on visceral glucose metabolism in steers. Pages 273-276 in Energy Metabolism in Animals. EAAP Publication No. 103. A. Chwalibog and K. Jakobsen, ed. Wageningen Press, Wageningen, the Netherlands.
Huntington, G. B., R. L. Prior, and R. A. Britton. 1980. Glucose and lactate absorption and metabolic interrelationships in lambs switched from low to high concentrate diets. J. Nutr. 110:19041913.

Ingvartsen, K. L. 2006. Feeding- and management-related diseases in the transition cow: Physiological adaptations around calving and strategies to reduce feeding-related diseases. Anim. Feed Sci. Technol. 126:175-213.

INRA. 2007. Alimentation des bovins, ovins et caprins-Besoins des animaux, valeurs des aliments-Tables INRA 2007. Quae, Versailles, France.

Katz, M. L., and E. N. Bergman. 1969. A method for simultaneous cannulation of the major splanchnic blood vessels of the sheep. Am. J. Vet. Res. 30:655-661.

Lapierre, H., C. E. Galindo, S. Lemosquet, I. Ortigues-Marty, L. Doepel, and D. R. Ouellet. 2010. Protein supply, glucose kinetics and milk yield in dairy cows. Pages 277-288 in Energy and protein metabolism and nutrition. EAAP Publication No. 127. G. M. Crovetto, ed. Wageningen Academic Publishers, Wageningen, the Netherlands.

Lapierre, H., G. E. Lobley, L. Doepel, G. Raggio, H. Rulquin, and S. Lemosquet. 2012. Mammary metabolism of amino acids in dairy. J. Anim. Sci. 90:1708-1721.

Larsen, M., C. Galindo, D. R. Ouellet, G. Maxin, N. B. Kristensen, and H. Lapierre. 2015. Abomasal amino acid infusion in postpartum transition dairy cows: Effect on splanchnic and mammary amino acid metabolism. J. Dairy Sci. 98:7944-7961. http://dx.doi. org/10.3168/jds.2015-9439.

Larsen, M., and N. B. Kristensen. 2009. Effect of abomasal glucose infusion on splanchnic and whole-body glucose metabolism in periparturient dairy cows. J. Dairy Sci. 92:1071-1083.

Larsen, M., and N. B. Kristensen. 2013. Precursors for liver gluconeogenesis in periparturient dairy cows. Animal 7:1640-1650.

Larsen, M., H. Lapierre, and N. B. Kristensen. 2014. Abomasal protein infusion in postpartum transition dairy cows: Effect on performance and mammary metabolism. J. Dairy Sci. 97:5608-5622.

Lemosquet, S., G. Raggio, G. E. Lobley, H. Rulquin, J. Guinard-Flament, and H. Lapierre. 2009. Whole-body glucose metabolism and mammary energetic nutrient metabolism in lactating dairy cows receiving digestive infusions of casein and propionic acid. J. Dairy Sci. 92:6068-6082.

Lobley, G. E., A. Connell, M. A. Lomax, D. S. Brown, E. Milne, A. G. Calder, and D. A. Farningham. 1995. Hepatic detoxification of ammonia in the ovine liver: Possible consequences for amino acid catabolism. Br. J. Nutr. 73:667-685.

Lobley, G. E., and H. Lapierre. 2003. Post-absorptive metabolism of amino acids. Pages 737-756 in Progress in Research on Energy and Protein Metabolism. W. B. Souffrant and C. C. Metges, ed. EAAP Publication No.109. Wageningen Academic Publishers, Wageningen, the Netherlands.

Lomax, M. A., and G. D. Baird. 1983. Blood flow and nutrient exchange across the liver and gut of the dairy cow. Effects of lactation and fasting. Br. J. Nutr. 49:481-496.

Loncke, C., I. Ortigues-Marty, J. Vernet, H. Lapierre, D. Sauvant, and P. Nozière. 2009. Empirical prediction of net portal appearance of volatile fatty acids, glucose, and their secondary metabolites ( $\beta$-hydroxybutyrate, lactate) from dietary characteristics in ruminants: A meta-analysis approach. J. Anim. Sci. 87:253-268.

Loor, J. J. 2010. Genomics of metabolic adaptations in the peripartal cow. Animal 4:1110-1139.

Majdoub, L., M. Vermorel, and I. Ortigues-Marty. 2003. Intraruminal propionate supplementation modifies hindlimb energy metabolism without changing the splanchnic release of glucose in growing lambs. Br. J. Nutr. 89:39-50.

Martineau, R., C. Benchaar, H. V. Petit, H. Lapierre, D. R. Ouellet, D. Pellerin, and R. Berthiaume. 2007. Effects of lasalocid or monensin supplementation on digestion, ruminal fermentation, blood metabolites, and milk production of lactating dairy cows. J. Dairy Sci. 90:5714-5725. 
NRC. 2001. Nutrient Requirements of Dairy Cattle. 7th rev. ed. Natl. Acad. Sci., Washington, DC.

Offner, A., and D. Sauvant. 2004. Prediction of in vivo starch digestion in cattle from in situ data. Anim. Feed Sci. Technol. 111:41-56.

Ørskov, E. R., D. A. Grubb, and R. N. B. Kay. 1977. Effect of postruminal glucose or protein supplementation on milk yield and composition in Friesian cows in early lactation and negative energy balance. Br. J. Nutr. 38:397-405.

Raun, B. M., and N. B. Kristensen. 2011. Metabolic effects of feeding ethanol or propanol to postpartum transition Holstein cows. J. Dairy Sci. 94:2566-2580.

Reynolds, C. K., P. C. Aikman, B. Lupoli, D. J. Humphries, and D. E. Beever. 2003. Splanchnic metabolism of dairy cows during the transition from late gestation through early lactation. J. Dairy Sci. 86:1201-1217.

Richards, C. J., K. C. Swanson, S. J. Paton, D. L. Harmon, and G. B. Huntington. 2003. Pancreatic exocrine secretion in steers infused postruminally with casein and cornstarch. J. Anim. Sci. 81:10511056.

SAS Institute. 2008. SAS/STAT software. Version 9.2. SAS Institute Inc., Cary, NC.

Seal, C. J., and D. S. Parker. 1994. Effect of intraruminal propionic acid infusion on metabolism of mesenteric- and portal-drained viscera in growing steers fed a forage diet: I. Volatile fatty acids, glucose, and lactate. J. Anim. Sci. 72:1325-1334.

Sjaunja, L. O., L. Bævre, L. Junkkarinen, J. Pedersen, and J. Setälä. 1991. A Nordic proposal for an energy corrected milk (ECM) for- mula. Pages 156-157 in Proc. 27th Session of International Committee for Recording Productivity of Milk Animals (ICRPMA) EAAP Publication No. 50. EAAP, Wageningen, the Netherlands.

Swanson, K. C., J. A. Benson, J. C. Matthews, and D. L. Harmon. 2004. Pancreatic exocrine secretion and plasma concentration of some gastrointestinal hormones in response to abomasal infusion of starch hydrolysate and or casein. J. Anim. Sci. 82:1781-1787.

van der Schoor, S. R. D., J. B. Van Goudoever, B. Stoll, J. F. Henry, J R. Rosenberger, D. G. Burrin, and P. J. Reeds. 2001. The pattern of intestinal substrate oxidation is altered by protein restriction in pigs. Gastroenterology 121:1167-1175.

Vernon, R. G. 2002. Nutrient partitioning, lipid metabolism and relevant imbalances. Pages 210-223 in Recent Developments and Perspectives in Bovine Medicine. M. Kaske, H. Scholz, and M. Holtershinken, ed. Klinik fur Rinderkrankheiten, Hanover, Germany.

Vernon, R. G. 2003 Adipose tissue: An expanding role in the regulation of energy metabolism. Pages 451-464 in Progress in Research on Energy and Protein Metabolism. EAAP Publication No. 109. W. B. Souffrant and C. C. Metges, ed. Wageningen Academic Publishers, Wageningen, the Netherlands.

Windmueller, H. G., and A. E. Spaeth. 1980. Respiratory fuels and nitrogen metabolism in vivo in small intestine of fed rats. Quantitative importance of glutamine, glutamate, and aspartate. J. Biol. Chem. 255:107-112.

Young, J. W. 1977. Gluconeogenesis in cattle: Significance and methodology. J. Dairy Sci. 60:1-15. 